\title{
Rebalancing the Interior
}

\author{
After the tumultuous weeks and months surrounding the 2020 United States presidential election, the President's \\ choice for a key post in his administration gives a broad outline of how land-use policy and politics could change \\ going forward.
}

$\mathrm{T}$ he Cabinet of the United States is made up of secretaries of federal departments who are nominated by the President but require a confirmation vote by the Senate. So far, the biggest headlines and toughest battle among President Biden's initial nominees have been focused on his pick for Secretary of the Interior, a department that affects the daily lives of many Americans. The Department of the Interior (DOI) does not handle security or policing, but land - and lots of it. Two hundred million hectares across the United States are directly overseen by this department as public lands of varying jurisdictions and protections, and represent $75 \%$ of the federal land portfolio. The DOI is composed of over a dozen agencies, including the Bureau of Reclamation, which handles the dams and reservoirs that much of the American West relies upon for irrigation; the National Park Service, which oversees natural treasures such as Yellowstone, Yosemite and Joshua Tree; and the Bureau of Indian Affairs, one of the oldest agencies in the United States government that works with Native American tribes and reservations on all aspects of daily and economic life.

Interior secretaries tend to come from the West, the region of most of the department's focus. The department provides leverage for enacting policy change, but can also be problematic. President Trump's first secretary, Ryan Zinke, was forced to step down within two years due to accusations of abusing the office for personal gain. He also performed a controversial 'review' of national parks that led to an unprecedented decision to reduce the Bears Ears National Monument in Utah by $85 \%$, a site considered sacred by Native American tribes in the area but which may also have uranium and thus be valuable for business ${ }^{1}$.

Given this recent history, President Biden's choice of candidate is significant. Deb Haaland, a member of the Laguna Pueblo tribe of New Mexico, served one term in Congress after years as a lawyer and businesswoman for her tribe ${ }^{2}$. She describes herself as a '35th-generation New Mexican' due to her ancestral heritage, and her community lived near a uranium mine that has since been declared a Superfund site (the highest federal government designation for environmental contamination), as drinking and irrigation water was affected by runoff from the mine, triggering serious health impacts. With this experience,

Haaland became involved in both activism and policy making. She participated in the Standing Rock protests of 2016 against the construction of the Dakota Access pipeline in North Dakota, which was thought to endanger the ecology and health of Sioux tribal lands as well as countless farms if the pipeline leaked into reservoirs and aquifers.

The selection of the first Native American to head the DOI was a major factor in the support for her nomination, as Haaland would be directly supervising both the Bureau for Indian Affairs and the Bureau for Land Management, and would therefore be responsible for reconciling competing interests for land use and conservation policies in and around tribal reservations which often connect with public lands ${ }^{3}$. Haaland will also be taking office at a time when the United States' national parks and monuments are facing numerous challenges, including maintenance backlogs, road construction, climate change and the effects of events during the Trump administration, which seemed to show an almost wilful aversion to protecting public lands and the ecosystems within them.

For example, construction of the Mexican 'border wall' has led to the uprooting and destruction of saguaro cacti within the Organ Pipe Cactus National Monument in Arizona, despite this being a UNESCO international biosphere reserve. These famous cacti can live for centuries and are protected by state law within a federal park. The Department of Homeland Security, responsible for the wall construction, claimed that $90 \%$ of the cacti were being replanted, but video footage taken last year showed hundreds cut up and laying on the ground $^{4}$. Organ Pipe is one of many sites of ecological concern caused by the border wall construction, which, according to the Fish and Wildlife Service, could cause massive disruptions for flora and fauna in the area ${ }^{5}$.

This is not an isolated incident. Under the Trump administration, the DOI took many actions that seemingly favoured resource development over preservation of public lands, including allowing oil drilling in the Alaskan National Wildlife Refuge (one of the last pieces of untouched frontier left on American soil), and attempting to sell mineral leases for nearly 13 million acres of federal lands ${ }^{6}$.

This history of DOI operations was not seen as a cautionary tale by Senate Republicans when voting on Haaland's nomination, but as a course to be maintained. Many of them were quite vocal in their view that Haaland was a dangerous choice due to her opposition to fracking on public land, the strong approval given to her by the League of Conservation Voters, and the Biden administration's announced moratorium on new oil and gas leases ${ }^{7}$. However, Haaland was ultimately approved by the 100 -member Senate, with key votes coming from moderate Republicans in what may indicate a desire to rebalance the DOI and its purpose.

That Haaland was chosen at all reflects a growing wave of support among Democrats and liberals for changes in land-use policy that has seemingly protected a status quo that favours business, as well as the notion that Native American tribes, environmentalists and the outdoor recreation industry are also stakeholders who should have equal weight in these decisions. Rebuilding the DOI after the previous administration will take time and energy, but proper leadership and a shift in outlook could lead to a new lasting legacy for public lands in the United States.

It is hoped that Deb Haaland will be given the time and space to restore the DOI's commitment to natural landscapes and public stewardship, and build a record that can be exported globally.

Published online: 19 April 2021

https://doi.org/10.1038/s41477-021-00909-x

References

1. Grant, W. On the hunt for uranium in Bears Ears. Outside https:// go.nature.com/39x4V62 (2018)

2. Puko, T. Interior secretary nominee on collision course with oil industry. The Wall Street Journal (14 February 2021); https:// go.nature.com $/ 2 \mathrm{PcJHUl}$

3. Necefer, D. The Department of the Interior shaped my life. Outside https://go.nature.com/3czThcy (2021).

4. Romero, S. Tribal nation condemns 'desecration' to build border wall. The New York Times (26 February 2020); https://go.nature. com/2PK8leE

5. Barclay, E. \& Frostenson, S. The ecological disaster that is Trump's border wall: a visual guide. Vox https://go.nature.com/2QIrFJN (2019).

6. Tobias, J. The Zinke effect: how the US interior department became a tool of big business. The Guardian (12 November 2018); https://go.nature.com/39umfZ

7. Fears, D. Deb Haaland's nomination to lead Interior is a historic first for Native Americans. The GOP wants Biden to cancel it. The Washington Post (19 February 2021); https://go.nature.com/3rLJ15D 